\title{
An assessment of the taxonomic status of the Mediterranean endemic genus Acrodiscus Zanardini (Halymeniales, Rhodophyta)
}

\author{
Antonio MANGHISI ${ }^{1, *}$, Line LE GALL ${ }^{2}$, Céline BONILLO $^{3}$, \\ Gaetano M. GARGIULO ${ }^{4}$, M. Antonia RIBEIRA ${ }^{5}$ \& Marina MORABITO $^{6}$ \\ 1,2,3 Institut de Systématique, Évolution, Biodiversité, ISYEB - UMR 7205 - CNRS, \\ MNHN, UPMC, EPHE, Muséum national d'Histoire naturelle, \\ Sorbonne Universités, 57 rue Cuvier, CP 39 75005, Paris, France. \\ 1,4,6 Dept. of Chemical, Biological, Pharmaceutical and Environmental Sciences - Botany, \\ University of Messina, Salita Sperone, 31, 98166 Messina, Italy. \\ ${ }_{1,5}^{1,5}$ Laboratori de Botànica, Facultat de Farmàcia, Universitat de Barcelona, \\ Av. Joan XXIII s/n, 08028 Barcelona, Spain. \\ *Corresponding author: amanghisi@unime.it \\ ${ }^{2}$ Email: legall@mnhn.fr \\ ${ }^{3}$ Email: bonillo@mnhn.fr \\ ${ }^{4}$ Email: ggargiulo@unime.it \\ ${ }^{5}$ Email: riberasiguan@ub.edu \\ ${ }^{6}$ Email: morabitom@unime.it
}

\begin{abstract}
Acrodiscus Zanardini is a poorly known monotypic endemic Mediterranean genus based on A. vidovichii (Menegh.) Zanardini. Rarely reported, its reproductive structures have remained undocumented, leaving its exact taxonomic position uncertain. Solely on the basis of its vegetative structure, Zanardini provisionally placed it in the family Cryptonemiaceae of the order Cryptonemiales (currently the Halymeniaceae of the Halymeniales), although he was uncertain as to whether the new genus actually belonged to that family or should instead be included in the Gigartinaceae of the Gigartinales (where Meneghini had originally placed it). In the present study we have extensively sampled A. vidovichii and documented its vegetative and tetrasporangial features. As well, we provide molecularsequence data (COI-5P, $r b c \mathrm{~L}, \mathrm{LSU})$ that indicate its phylogenetic affinities. We confirm Acrodiscus as a member of the Halymeniaceae and its status as an independent genus. Searches of several institutional herbaria have allowed us to locate and lectotypify Meneghini's Chondrus? vidovichii by the discovery of his original material now held at the Herbarium Horti Pisani (Pisa, Italy).
\end{abstract}

Keywords. Acrodiscus, DNA barcoding, Mediterranean endemic, lectotype, morphology, phylogeny.

Manghisi A., le Gall L., Bonillo C., Gargiulo G.M., Ribeira M.A. \& Morabito M. 2017. An assessment of the taxonomic status of the Mediterranean endemic genus Acrodiscus Zanardini (Halymeniales, Rhodophyta). European Journal of Taxonomy 267: 1-24. http://dx.doi.org/10.5852/ejt.2017.267

\section{Introduction}

Acrodiscus Zanardini is a poorly known and persistently enigmatic genus endemic to the Mediterranean Sea. Based on Chondrus? vidovichii Menegh. (Savi 1841), it was later proposed as the type and only 
species of the genus Acrodiscus by Zanardini (1868) based on vegetative structure and position of the tetrasporangial sori. Throughout its long history it has only rarely been collected, is known only from asexual material, and has remained of uncertain family affinity. Zanardini (1868) provisionally placed the genus in the Cryptonemiaceae (currently the Halymeniaceae), but he questioned whether the new genus was correctly placed in that family or whether it should instead be included in the Gigartinaceae. In the absence of female reproductive structures, it has not been possible to relate Acrodiscus to existing members of the Halymeniaceae owing to the importance of carpogonial and auxiliary-cell "ampullae" in the taxonomy of that family (Chiang 1970; Gargiulo et al. 2013; Saunders \& Kraft 1996). Halymeniacean vegetative structures are on the contrary quite similar to those of other families within the Gigartinales. Presumably based on the similarity of morphology and presence of tetrasporangial sori, Schmitz (1889) proposed that A. vidovichii should be transferred to the genus Polyopes. Guiry \& Guiry (2016) have suggested that Acrodiscus is congeneric with Cryptonemia, although it lacks the differentiated stipes and especially the refractive medullary cells typical of that genus (Kraft \& Saunders 2014: 165).

The aim of the present study is to ascertain the taxonomic position of $A$. vidovichii through several lines of evidence that include DNA-sequence data, a thorough description of both vegetative and tetrasporangial features, and the full characterization of the type material on which our lectotypification is based.

\section{Material and Methods}

Specimens from several localities (Table 1) were used for anatomical and DNA studies.

Fresh material was pressed as herbarium specimens, with fragments preserved in $4 \%$ formalin for permanent wet-preservation or dried in silica gel for molecular studies. Vouchers are housed in the Herbarium of the University of Barcelona, Spain (BCN-Phyc), the Muséum national d'Histoire naturelle in Paris, France (PC), or in the Herbarium Messanaensis of the University of Messina, Italy (MS). Additional material (dried or formalin preserved) was examined in the herbaria of Spanish universities and institutions involved in the project "Flora Phycologica Iberica" (Manghisi et al. 2010a). For the lectotypification, the Herbarium Centrale Italicum of Florence (FI), the herbarium of the Civic Natural History Museum of Venice (MCVE), the Herbarium Patavinum of the University of Padua (PAD), the Herbarium Horti Botanici Pisani of the University of Pisa (PI), the herbarium of the University of Leiden (L), the herbarium of the Natural History Museum in London (BM), and the cryptogamic herbarium of the Muséum national d'Histoire naturelle in Paris (PC) were searched for type material (Table 2; Appendix 1). Herbarium designations are given as directed by the Index Herbariorum (Thiers continuously updated).

For morpho-anatomical observations, thalli were hand-sectioned with single-edged razor blades, stained with $1 \%$ aniline blue, and observed using a Nikon Optiphot-2 equipped with a Nikon Coolpix 4500 camera (Leica Microsystems, Italy).

Sequence data generated for COI-5P, $r b c \mathrm{~L}$ and LSU genes were submitted to BOLD (http://www. barcodinglife.org) and to GenBank (Clark et al. 2016). Accession numbers, together with collection information, are given in Table 1.

DNA extraction was performed as outlined in Manghisi et al. (2010b). The barcode region COI-5P was PCR amplified as detailed in Saunders \& McDevitt (2012), the nuclear LSU rRNA gene was PCR amplified as detailed in Harper \& Saunders (2001), and the plastid $r b c$ L gene was amplified with various primer combinations as specified by Freshwater \& Rueness (1994) and Wang et al. (2000).

Sequences were generated using the BigDye Terminator v. 3.1 Cycle Sequencing Kit (PE Applied Biosystems [ABI], Foster City, CA, USA) and analyzed using an ABI Prism 3130XL genetic analyzer at 


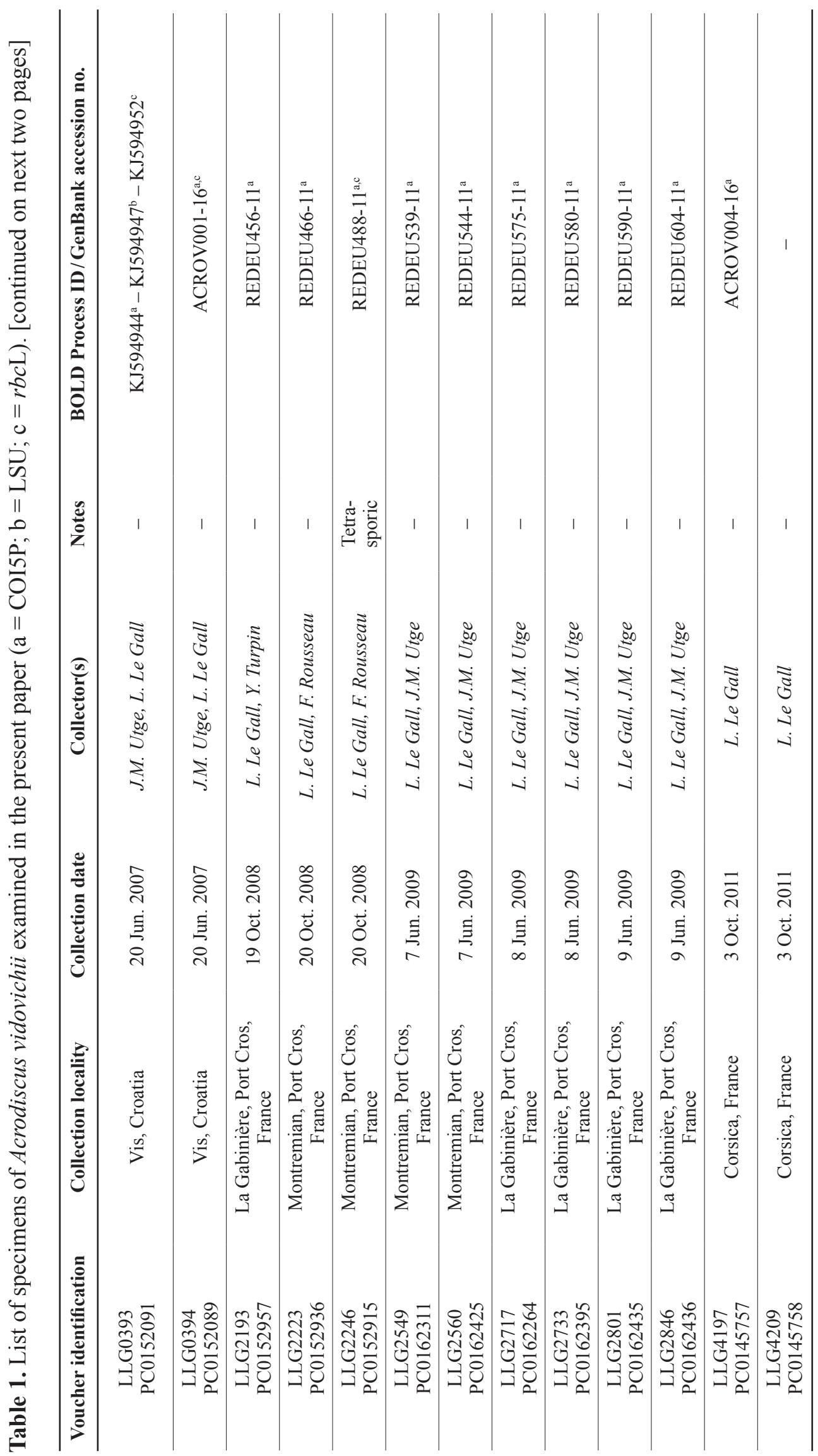




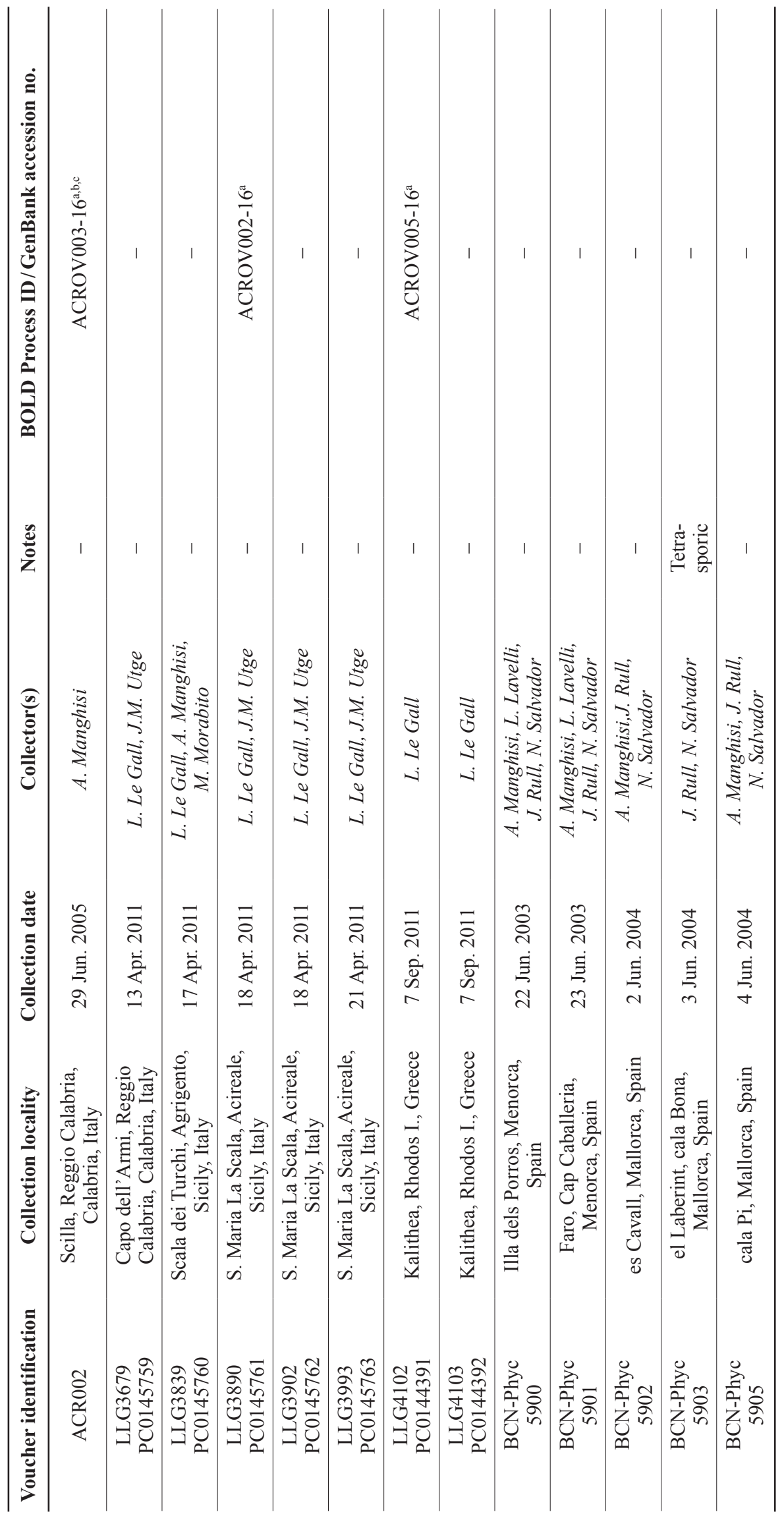




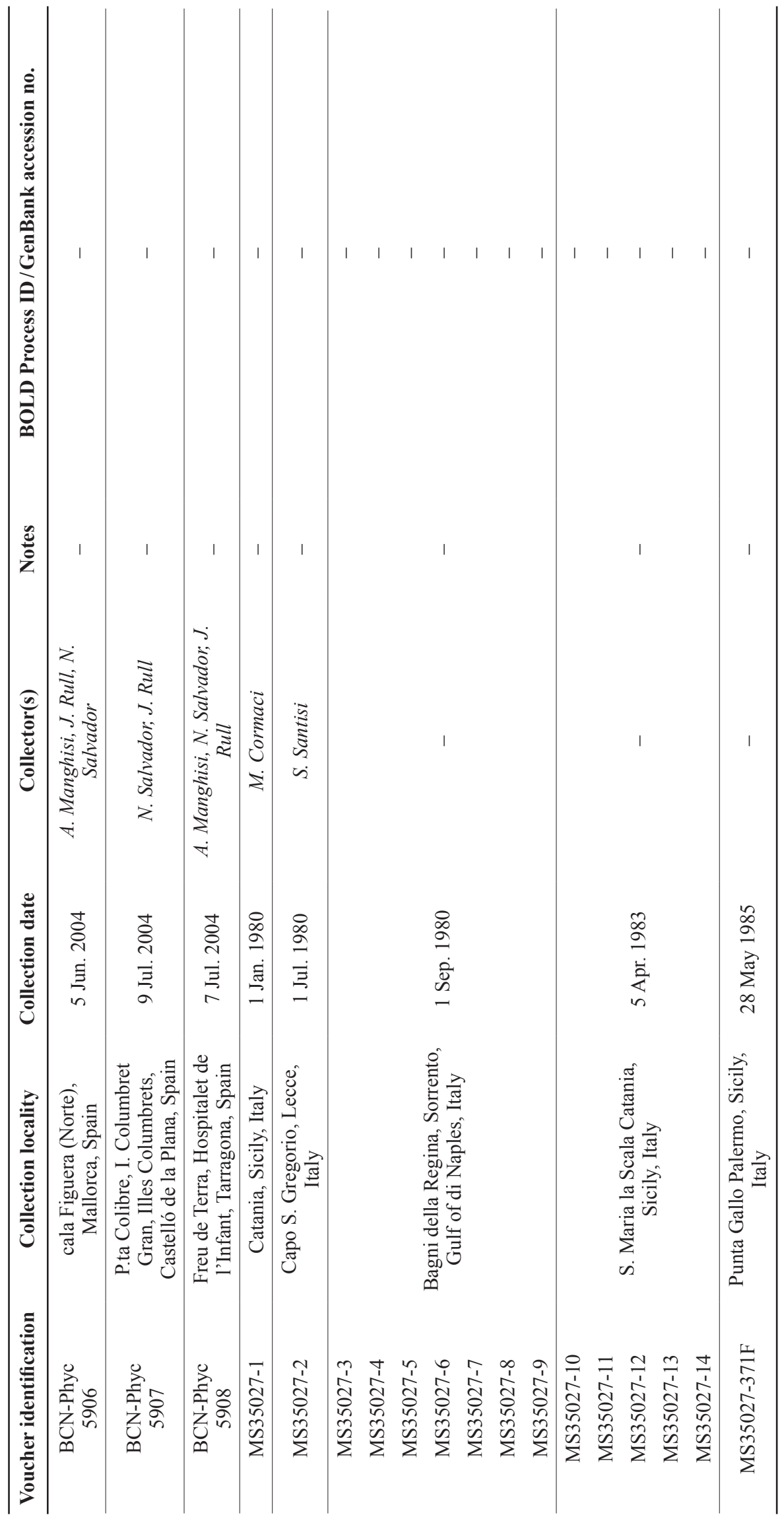


the CEMAR, University of New Brunswick, Canada, or an ABI Prism 3730XL at the Genoscope (www. genoscope.fr) in Evry, France. Forward and reverse sequence reads were assembled into contigs with the software ChromasPro (v. 1.7.6.1, Technelysium Pty Ltd) and edited. Multiple sequence alignments were constructed in SeaView v. 4.3.3 (Gouy et al. 2010) and included both data from GenBank and sequences generated for the present study. Newly generated COI-5P sequences were subjected to distance analysis in PAUP* (Swofford 2002).

For $r b c \mathrm{~L}$ analyses, an initial alignment of 728 sequences and 1258 nucleotide positions was subjected to neighbor-joining (NJ) distance analysis under a K2 nucleotide substitution model in PAUP* to identify species groups. The resulting tree was used to prepare a second alignment for subsequent phylogenetic analyses with 36 sequences representative of most genera of the order Halymeniales, including the generitypes, by the exclusion of duplicate or similar sequences (poor quality sequences, i.e., those missing more than $30 \%$ of data, were also removed), and 1211 nucleotide positions.

Similarly, an initial alignment was built with 122 LSU sequences and 2921 nucleotide positions, from which, after NJ analyses performed as above, a fourth alignment was built with 33 LSU sequences representative of most genera of Halymeniales, including the generitypes, and 2640 nucleotide positions, excluding those ambiguously aligned.

A fifth alignment consisted of the concatenation of LSU and $r b c \mathrm{~L}$ sequences for the same species and, when possible, for the same specimen, these including 21 sequences and 3820 nucleotide positions. GenBank accession numbers of sequences used for the final alignments are listed in Table 3.

All phylogenetic analyses were performed in MrBayes v. 3.1.2 or 3.2.1 (parallel version; Altekar et al. 2004; Ronquist \& Huelsenbeck 2003), RAxML (online version, http://embnet.vital-it.ch/raxml-bb/; Stamatakis et al. 2008), and PhyML 3.0 (online version, http://atgc.lirmm.fr/phyml; Guindon \& Gascuel 2003).

Maximum Likelihood analyses were performed with bootstrap resampling to estimate robustness of the internal nodes (Felsenstein 1985), based on 1000 replicates in PhyML, with a GTR+G+I substitution model (with all parameters estimated during the search), starting from ten random BIONJ trees (Gascuel 1997) with subtree pruning and regrafting (SPR) as branch-swapping algorithm. Furthermore, Maximum Likelihood (ML) analyses were also performed with bootstrap resampling based on 100 replicates in RAxML, with a GTR $+\mathrm{G}+\mathrm{I}$ substitution model with three partitions for $r b c \mathrm{~L}$, corresponding to each codon position, and with four partitions for the concatenate analyses corresponding to LSU and each codon position of $r b c \mathrm{~L}$.

For Bayesian inference both the $r b c \mathrm{~L}$ and the concatenate data sets were also partitioned as above. The covarion-like model (Huelsenbeck 2002) was combined with the GTR $+\mathrm{G}$ model of sequence evolution linking or unlinking parameters among partitions (shape, statefreq, revmat, switchrates, Tratio) and setting the prior for the site specific rates as "variable". Different analytical strategies were tested in order to reach convergence. Each analysis consisted of two parallel runs, each run using four chains, one cold and three incrementally heated.

A single run consisted of 5 million generations that were sampled every $1000^{\text {th }}$ tree. After completion of the two runs, likelihood values were plotted against the number of generations to evaluate when MCMC chains reached stability, in order to set an appropriate burn-in value for each analysis. Only trees saved during the stationary phase were used to reconstruct a majority-rule consensus tree and calculate the distribution of posterior probabilities.

In all phylogenetic analyses, unrooted trees were constructed, the root being subsequently designated based on previous knowledge (Withall \& Saunders 2006). 


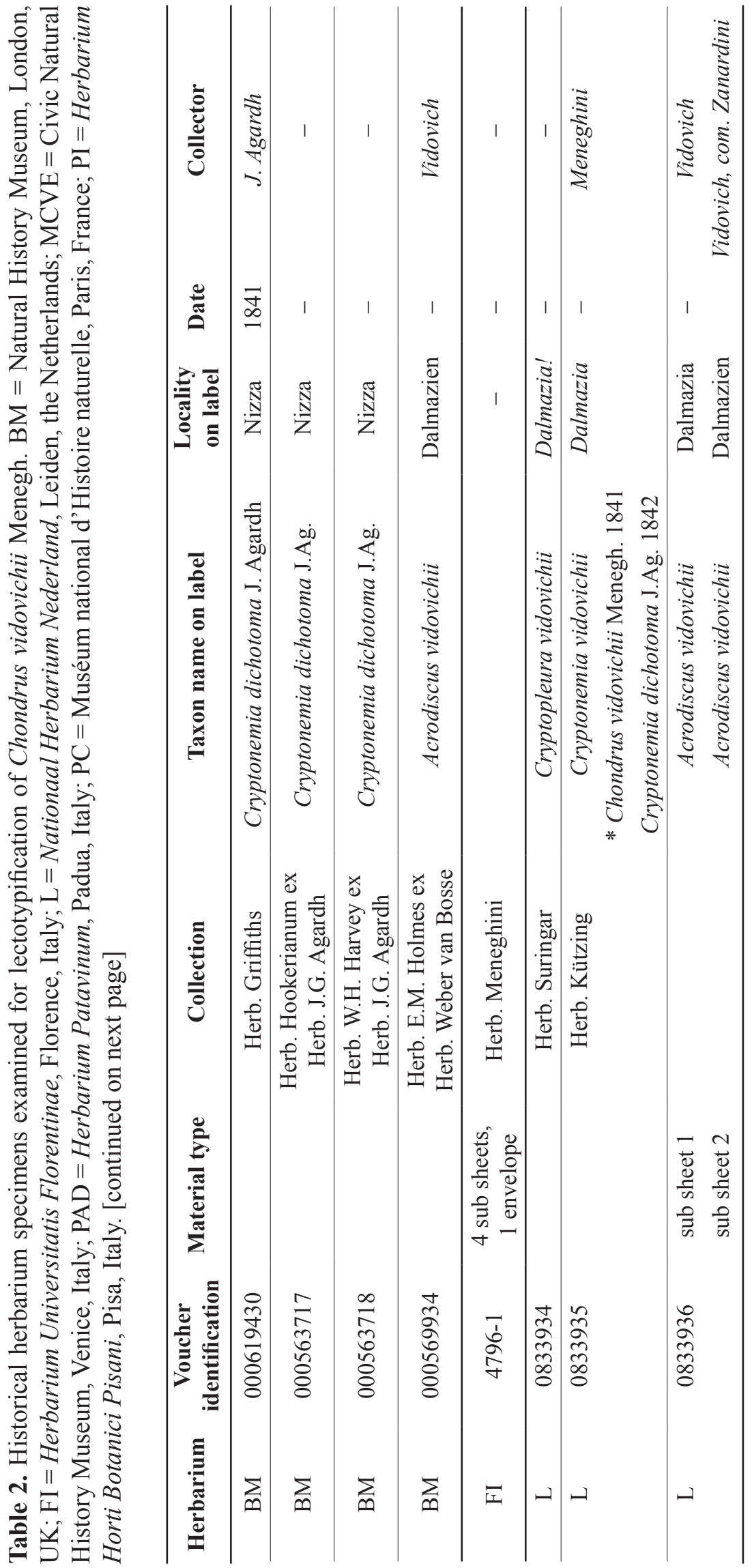




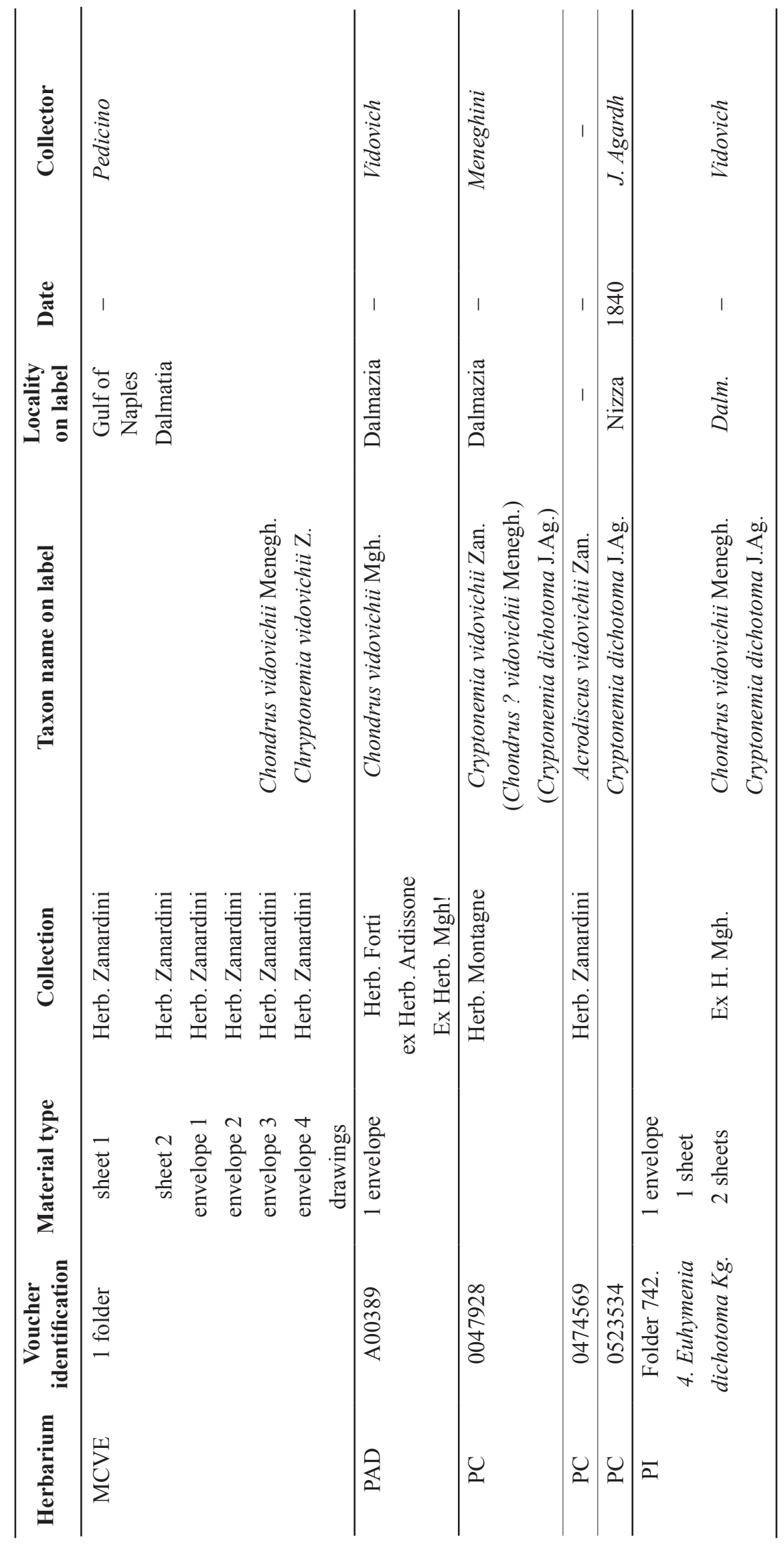


MANGHISI A. et al., Taxonomic status of Acrodiscus (Halymeniales, Rhodophyta)

Table 3. List of sequences from GenBank used in phylogenetic analyses.

\begin{tabular}{|c|c|c|}
\hline \multirow[b]{2}{*}{ Species } & \multicolumn{2}{|c|}{ GenBank accession numbers } \\
\hline & LSU & $\operatorname{rbcL}$ \\
\hline Aeodes nitidissima J.Agardh & GWS1525 ${ }^{1}$ & - \\
\hline Aeodes nitidissima J.Agardh & - & KJ739733 \\
\hline Amalthea freemaniae D’Archino \& W.A.Nelson & - & KJ606651 \\
\hline Carpopeltis phyllophora (J.D.Hooker \& Harvey) F.Schmitz & - & FN908164 \\
\hline Codiophyllum natalense J.E.Gray & - & FN908160 \\
\hline Corynomorpha prismatica (J.Agardh) J.Agardh & KJ594950 & KJ594955 \\
\hline Cryptonemia lomation (Bertoloni) J.Agardh & KJ594948 & KJ594953 \\
\hline Cryptonemia luxurians (C.Agardh) J.Agardh & - & AB061374 \\
\hline Cryptonemia rotunda (Okamura) Kawaguchi & - & AB061375 \\
\hline Cryptonemia undulata Sonder & AF419133 & - \\
\hline Dermocorynus dichotomus (J.Agardh) Gargiulo, M.Morabito \& Manghisi & KJ511247 & - \\
\hline Dermocorynus horridus (Kützing) Gargiulo, M.Morabito \& Manghisi & KJ511244 & - \\
\hline Dermocorynus montagnei P.Crouan \& H.Crouan & - & AY435171 \\
\hline Epiphloea bullosa (Harvey) De Toni & DQ343693 & - \\
\hline Epiphloea bullosa (Harvey) De Toni & - & FN908149 \\
\hline Felicinia marginata (Roussel) Manghisi, Le Gall, Ribera, Gargiulo \& M.Morabito & KJ594949 & KJ594954 \\
\hline Galene profundae D'Archino \& Zuccarello & - & KJ606645 \\
\hline Gelinaria ulvoidea Sonder & GQ471910 & - \\
\hline Gelinaria ulvoidea Sonder & - & FN908154 \\
\hline Glaphyrosiphon intestinalis (Harvey) Leister \& W.A.Nelson & - & GU252166 \\
\hline Glaphyrosiphon aucklandicus (Montagne) W.A.Nelson, S.Y.Kim \& S.M.Boo & - & KJ739734 \\
\hline Grateloupia filicina (J.V.Lamouroux) C.Agardh & KJ511243 & JX070629 \\
\hline Grateloupia ovata Womersley \& J.A.Lewis & GQ471911 & - \\
\hline Grateloupia proteus Kützing & KJ511245 & - \\
\hline Halymenia abyssicola E.Y.Dawson & - & GU598119 \\
\hline Halymenia actinophysa M.Howe & - & GU598118 \\
\hline Halymenia dilatata Zanardini & - & $\mathrm{AB} 038604$ \\
\hline Halymenia floresii (Clemente) C.Agardh & KJ594951 & KJ594956 \\
\hline Halymenia maculata J.Agardh & GQ471913 & - \\
\hline Halymenia maculata J.Agardh & - & AB061397 \\
\hline Halymenia plana Zanardini & GQ471914 & - \\
\hline Halymenia pseudofloresii Collins \& M.Howe & GQ471915 & - \\
\hline Halymeniales sp. & GQ471916 & - \\
\hline Isabbottia ovalifolia (Kylin) Balakrishnan & EF033616 & KM360033 \\
\hline Kintokiocolax aggregato-ceranthus Tak.Tanaka \& Y.Nozawa & - & KF475733 \\
\hline Mariaramirezia osornoensis M.S.Calderon, G.H.Boo, A.Mansilla \& S.M.Boo & - & AF488827 \\
\hline Norrissia setchellii (Kylin) Balakrishnan & DQ343694 & - \\
\hline Pachymenia carnosa (J.Agardh) J.Agardh & DQ343695 & - \\
\hline Pachymenia carnosa (J.Agardh) J.Agardh & - & AF385640 \\
\hline Pachymenia cf. orbicularis (Zanardini) Setchell \& N.L.Gardner & DQ343696 & - \\
\hline Pachymenia lusoria (Greville) J.Agardh & GQ471917 & - \\
\hline Pachymenia orbicularis (Zanardini) Setchell \& N.L.Gardner & GQ471918 & - \\
\hline Pachymeniopsis gargiuli S.Y.Kim, A.Manghisi, M.Moribato \& S.M.Boo & KJ511246 & - \\
\hline Phyllymenia belangeri (Bory de Saint-Vincent) Setchell \& N.L.Gardner & AY772035 & - \\
\hline Polyopes constrictus (Turner) J.Agardh & DQ343697 & - \\
\hline Polyopes constrictus (Turner) J.Agardh & - & AB084535 \\
\hline Polyopes lancifolius (Harvey) Kawaguchi \& Wang & KF543072 & - \\
\hline Polyopes tasmanicus (Womersley \& J.A.Lewis) Kawaguchi \& J.A.Lewis & GQ471919 & - \\
\hline Prionitis lanceolata (Harvey) Harvey & - & AY772037 \\
\hline Prionitis sternbergii (C.Agardh) J.Agardh & EF033617 & - \\
\hline Spongophloea tissotii (Weber van Bosse) Huisman, De Clerck, et al. & - & FN908162 \\
\hline Thamnoclonium dichotomum (J.Agardh) J.Agardh & - & FN908152 \\
\hline Thamnoclonium latifrons Endlicher \& Diesing & - & FN908158 \\
\hline Tsengia comosa (Harvey) Womersley \& Kraft & DQ343702 & - \\
\hline Tsengia laingii (Kylin) Womersley \& Kraft & DQ343703 & - \\
\hline Tsengia lanceolata (J.Agardh) Saunders \& Kraft & DQ343701 & - \\
\hline Tsengia lanceolata (J.Agardh) Saunders \& Kraft & - & AY294386 \\
\hline Yonagunia tenuifolia Kawaguchi \& Masuda & - & AB116248 \\
\hline Zymurgia chondriopsidea (J.Agardh) J.A.Lewis \& Kraft & DQ343698 & KM360035 \\
\hline
\end{tabular}

${ }^{1}$ LSU sequence unpublished, courtesy of Dr. Gary W. Saunders, University of New Brunswick, Fredericton, NB, Canada. 


\section{Results}

Phylum Rhodophyta Wettst. (Wettstein 1901)

Subphylum Eurhodophytina G.W.Saunders \& Hommers. (Saunders \& Hommersand 2004)

Class Florideophyceae Cronquist (Cronquist 1960)

Subclass Rhodymeniophycidae G.W.Saunders \& Hommers. (Saunders \& Hommersand 2004)

Order Halymeniales G.W.Saunders \& Kraft (Saunders \& Kraft 1996)

Family Halymeniaceae Bory (Bory de Saint-Vincent 1828)

Genus Acrodiscus Zanardini (Zanardini 1868)

Acrodiscus vidovichii (Menegh.) Zanardini

Figs 1-7; Tables 1-2

Memorie del Reale Istituto Veneto di Scienze, Lettere ed Arti 14: 201 (1868). - Chondrus? vidovichii Menegh. in Savi, Sezione di Botanica, e Fisiologia Vegetabile, Adunanza del di 16 Settembre 1841. In: Atti della terza Riunione degli Scienziati Italiani tenuta in Firenze: 427 (1841). - Cryptonemia vidovichii (Meneghini) Zanardini, Saggio di classificazione naturale delle Ficee: 42 (1843). Euhymenia dichotoma (J.Agardh) Kütz. var. vidovichii Menegh. ex Kütz., Tabulae phycologicae; oder, Abbildungen der Tange. Vol. 17: 22, tab. 72 (1867). - Lectotype (designated here): Dalmatia [Šibenik, Croatia], Jul. 1841, Vidovich folder 742.4, n.11, fragments at the top and at the bottom left (PI!) (Fig. 7).

Cryptonemia dichotoma J.Agardh, Algae maris Mediterranei et Adriatici: 100 (1842). - Cryptonemia (section Acrodiscus) dichotoma J.Agardh, Species genera et ordines algarum: 225 (1851). - Euhymenia dichotoma (J.Agardh) Kütz., Species algarum: 742 (1849). - Type: France, Nice, near St. Hospice, 1841, J. Agardh s.n. (LD, BM!, BM000619430, PC!, PC0523534).

Acrodiscus vidovichii Zanardini f. cochlearis Erceg., Acta Adriatica IV: 76 (1949). syn. nov. - Type: Adriatic, Croatia.

\section{Description}

Thalli up to $10 \mathrm{~cm}$ in length, the blade segments typically $1-3 \mathrm{~cm}$ long by (4-)7(-10) $\mathrm{mm}$ broad by 200-250 $\mu \mathrm{m}$ thick (Fig. 1), compressed to flattened, thin, membranous-fleshy, dark red in color, erect from a very short cuneate stipe with a discoid holdfast, the blades subdichotomously branched, linear and slightly channeled, the apices broadly rounded (Figs 1C-D, 2A, 3A). Constrictions occasional between forks (Fig. 1D) and especially at sites of branching (Fig. 1B, D); proliferous blades frequent at constrictions (Fig. 1B) or from lower stipes (Fig. 1B-D).

Fronds multiaxial (Fig. 2A), the cortex anticlinal (Fig. 2A-B), the medulla densely filamentous (Fig. 2D); cortical filaments 5- or 6-layered, pseudo-dichotomously branched, the cells subspherical to ellipsoid (Fig. 2B), progressively smaller outwardly, 5-9 $\mu \mathrm{m}$ in diameter proximally, 2-3 $\mu \mathrm{m}$ in diameter at surface (Fig. 2B) and evenly spaced or slightly paired (Fig. 2C). Subsurface cortical cells secondarily pit-connected; short longitudinal multicellular 'bridges' sometimes linking adjacent cortical cells or growing into the medulla from the transition zone between cortex and medulla; stellate ("ganglionic" sensu Womersley \& Lewis 1994) and refractive medullary cells or filaments absent. Medulla occupying half of the blade sections, composed of interwoven longitudinal or, less commonly, oblique and transverse filaments ca $5 \mu \mathrm{m}$ in diameter (Fig. 2D).

Female and male reproductive structures not observed. Tetrasporangia developing in eliptical nemathecia located subapically (Fig. 3A). Tetrasporangial filaments usually three-celled, the terminal cell a cruciate/ decussate-cruciate tetrad (30-)33(-35) $\mu \mathrm{m}$ long by 12-15 $\mu \mathrm{m}$ wide (Fig. 3C-D); subapical cells ellipsoid, bearing two simple or once-dichomous sterile filaments that surround the sporangia (Fig. 3C); basal 
cells deltoid, sterile nemathecial paraphyses four-celled (Fig. 3C), the proximal cells narrowly falcate, the terminal cells smaller in diameter and subspherical (Fig. 3C).

\section{Distribution and habitat}

Acrodiscus is uncommon but widely distributed across the Mediterranean Sea (Fig. 4; see also Guiry \& Guiry 2016; Manghisi et al. 2010a); it is a sciaphilous species, found throughout the year on rocky substrata from depths of 0-50 m. Tetrasporophytes were collected in spring and autumn (Table 1).

\section{Taxonomic history}

In the year following Meneghini's (Savi 1841) proposal of Chondrus? vidovichii from Dalmatia [collected by Vidovich, fide Zanardini (1868)], J. Agardh (1842) described Cryptonemia dichotoma from collections near Nice. Zanardini (1843) soon after regarded Chondrus? vidovichii and Cryptonemia dichotoma as conspecific and a true member of Cryptonemia, creating Cryptonemia vidovichii based on Meneghini's prior naming. Apparently disregarding Zanardini's (1843) proposals, Kützing (1849) transferred C. dichotoma to his own new genus Euhymenia, which is now regarded as synonymous with Kallymenia

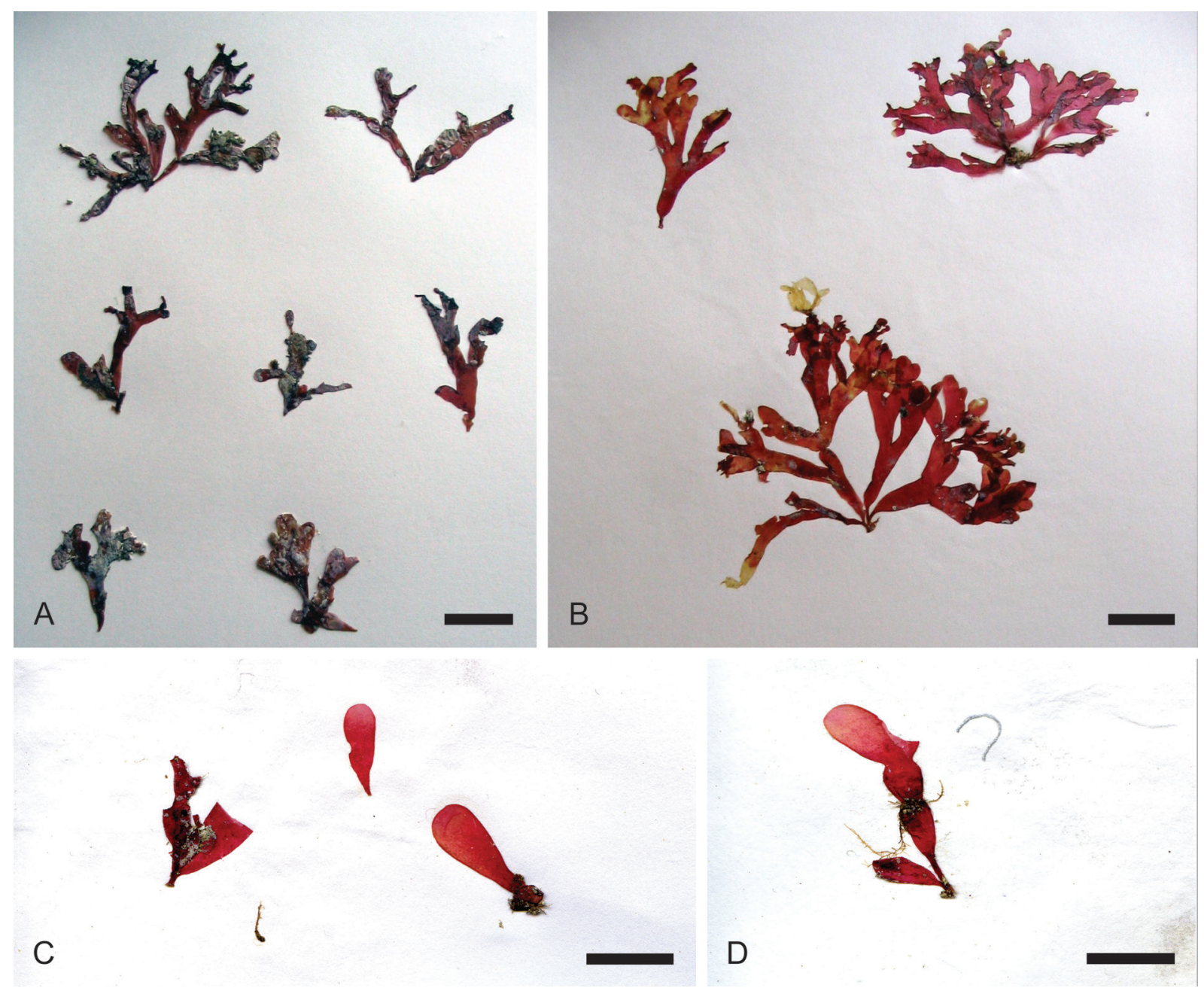

Fig. 1. A-B. Herbarium sheets MS35027-1 and MS35027-14, respectively, both from Sicily. C-D. Herbarium sheets PC0152091 (LLG0393) and PC0152089 (LLG0394), respectively, both from Vis Island, Croatia. Scale bars: $A-B=2 \mathrm{~cm} ; \mathrm{C}-\mathrm{D}=1 \mathrm{~cm}$. 
(Guiry \& Guiry 2016). Next, J.Agardh (1851), ignoring Kützing's Euhymenia, put Cryptonemia vidovichii into his newly proposed section Acrodiscus of Cryptonemia, along with Phyllophora crenulata J.Agardh and $C$. denticulata J.Agardh, on the base of their morphology and the presence of subapical tetrasorangial sori. Kützing (1867) then made Meneghini's species a variety of J. Agardh's Cryptonemia dichotoma, thus not acknowledging the synonymy of the two as had been advocated by Zanardini (1843). Soon afterwards, Zanardini (1868) removed Cryptonemia vidovichii (which he still regarded as synonymous with $C$. dichotoma) from the genus Cryptonemia and placed it into a newly created one, Acrodiscus, named after the section made by J. Agardh. De Toni (1905) transferred J. Agardh's C. crenulata and C. denticulata to Acrodiscus (as A. crenulatus (J.Agardh) De Toni and A. denticulatus (J.Agardh) De Toni), although both are currently regarded as genuine species of Cryptonemia (Guiry \& Guiry 2016).
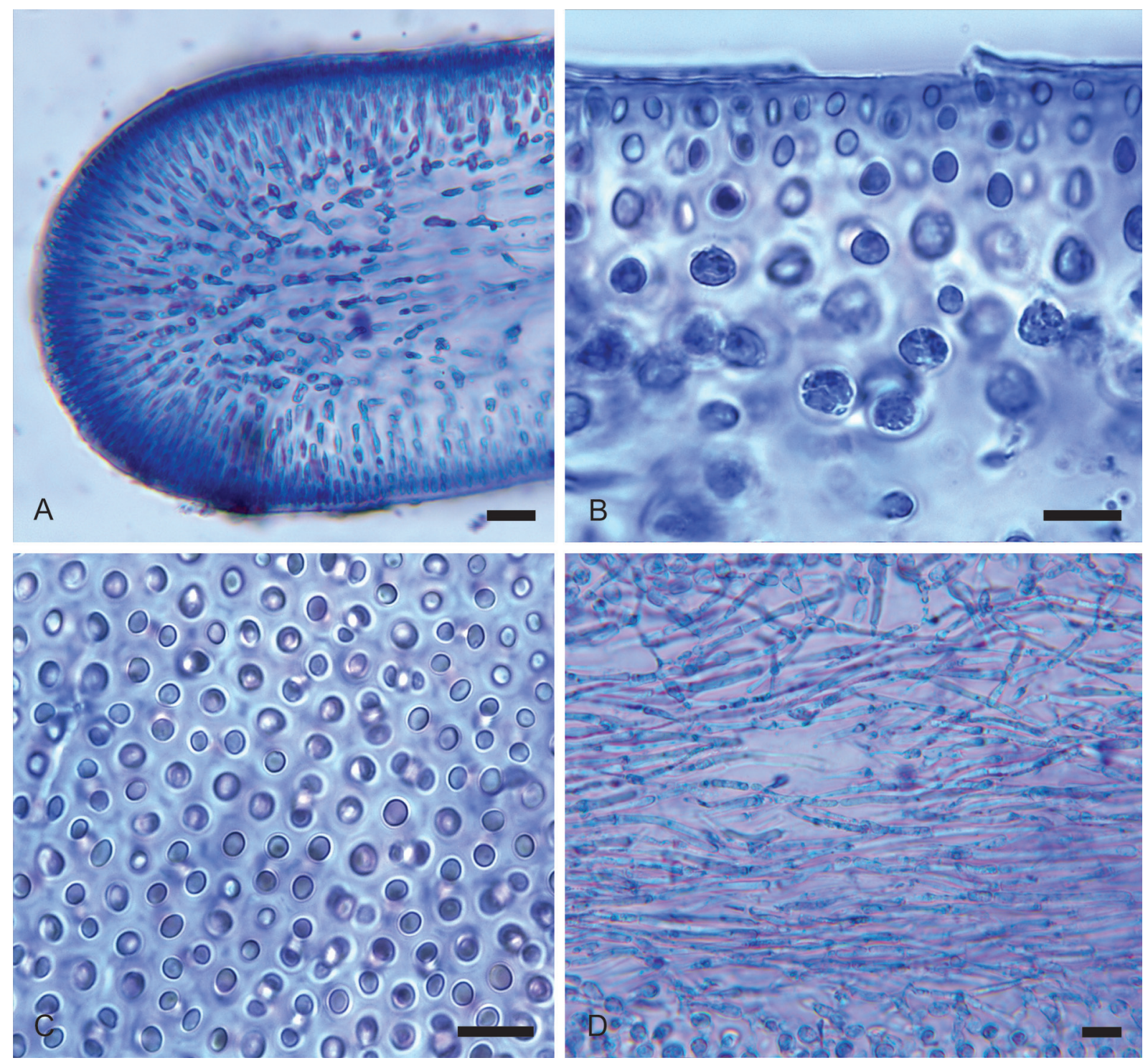

Fig. 2. Analine-blue stained vegetative features. A. A transapical longitudinal section indicative of its multiaxial structure. B. The anticlinal orientation of pseudo-dichotomous cortical filaments. C. Mostly paired cortical cells in surface view. D. Longitudinally aligned, peripherally inverwoven medullary filaments. Scale bars: A, D $=20 \mu \mathrm{m}$; $\mathrm{B}-\mathrm{C}=10 \mu \mathrm{m}$. 
In 1949, Ercegović proposed Acrodiscus vidovichii f. cochlearis, arguing that the specimens from Dalmatia (Croatia) had "spoon-shaped", rather than the flattened fronds described by several other workers (Ardissone 1883; Hauck 1885; Preda 1908; Zanardini 1868). Ercegović overlooked, however, the fact that populations from throughout the Mediterranean had been described as both compressed-flat or plane (Ardissone 1883; Hauck 1885; Kylin 1956; Savi 1841; Preda 1908; Zanardini 1868) and with bent/curved sub-grooved margins (Agardh 1842; Aleem 1993; De Toni 1905; Feldmann 1939). In our experience, freshly collected specimens normally have bent/curved margins but flatten once pressed on herbarium sheets; younger and thinner specimens, on the other hand, can be planar throughout and usually adhere to paper, whereas older, more coriaceous specimens may remain canaliculate and nonadherent. We therefore find little reason to recognize a separate forma cochlearis.

\section{Lectotypification}

Chondrus? vidovichii Menegh. was validly published in what is commonly reported as Menghini's Algologia Dalmatica (Guiry \& Guiry 2016) in Atti della terza Riunione degli Scienziati italiani tenuta in

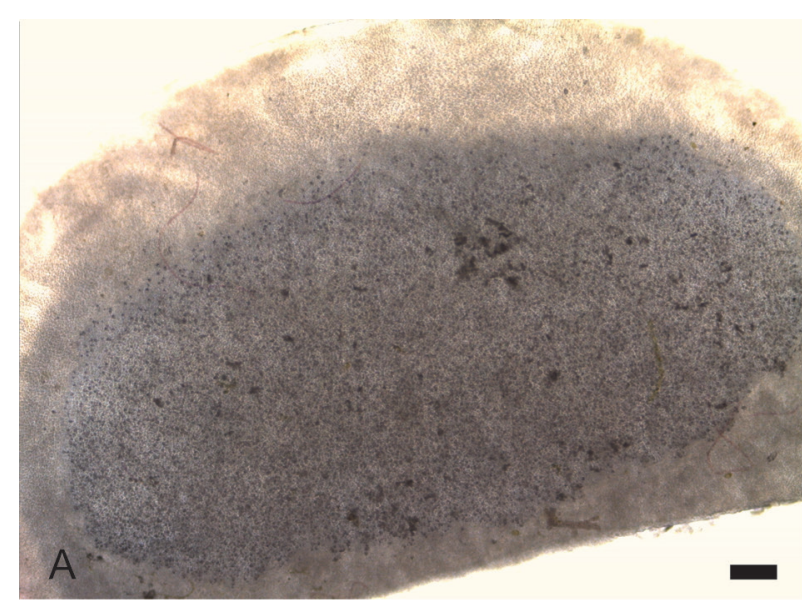

C

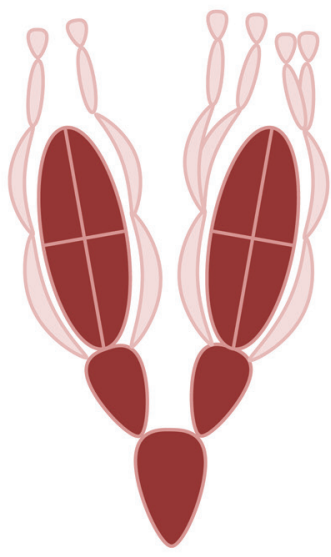

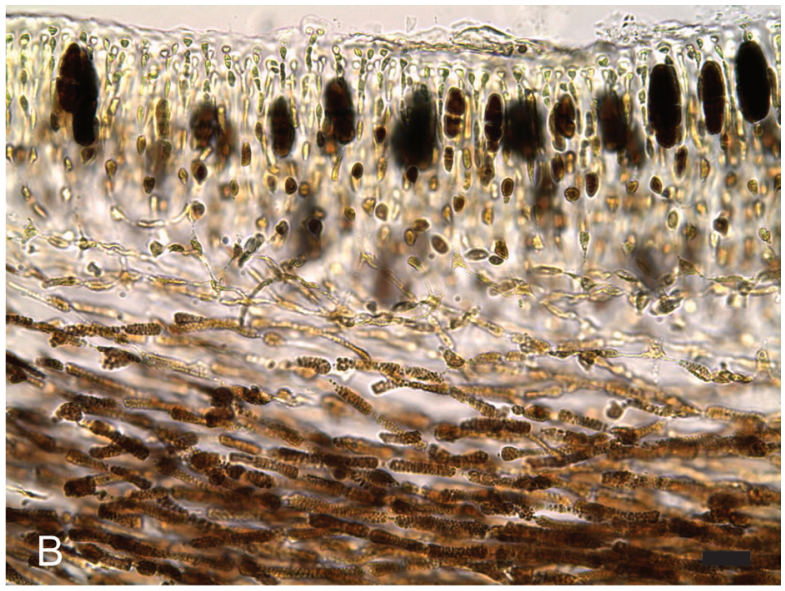

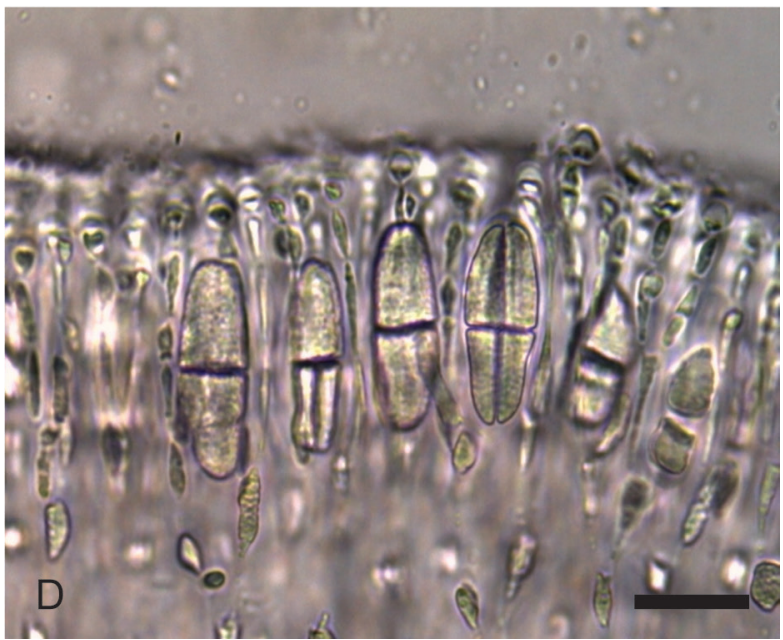

Fig. 3. A. Elliptical outline of a subapical nemathecial sorus. B. Lugol-stained 1.s. of a tetrasporangial nemathecium. C. Schematic drawing of terminal tetrasporangia and jacketing nemathecial filaments. D. Horizontally aligned cruciate and decussate-cruciate tetrasporangia within the palisade of nemathecial filaments. Scale bars: A $=200 \mu \mathrm{m} ; \mathrm{B}, \mathrm{D}=20 \mu \mathrm{m}$. 
Firenze nel Settembre 1841 (Savi 1841). Indeed, the latter is a congress acta in the form of a book with various sections. During the meeting of the Botany and Plant Physiology group, Meneghini showed his manuscript to the assembly. The secretary of the group, Pietro Savi, recorded the meeting events in the acta, and transcribed part of Meneghini's manuscript, reportedly titled Algologia Dalmatica, including its novelties. With specific reference to Chondrus? vidovichii, Savi copied the Latin diagnosis and noted the lack of reproductive structures, and made reference to an illustration that does not appear in the acta. No holotype is designated, nor is there an iconotype that might serve as one.

In the Library of Natural and Environmental Sciences of the University of Pisa, Italy, we found numerous manuscript documents belonging to Meneghini, among them the original complete manuscript of the so-called Algologia Dalmatica, actually Alghe Dalmate, enumerate ed illustrate dal professor Giuseppe Meneghini (Fig. 5 A-B), along with plates including his illustration of Chondrus? vidovichii (Fig 6). Unfortunately, the manuscript was never published.

Interestingly, in other documents there is evidence that: a) Meneghini received material from Dalmatia (Croatia) collected either by Vidovich in Sebenico (Šibenik), by Sandri in Zara (Zadar), or by Stalio in Spalato (Split); b) Menegnini received material from Vidovich in July 1841 (including a Chondrus?); and c) Meneghini dedicated to Vidovich all the new species collected by him. Consequently, it can be inferred that the type material should have been collected by Vidovich in Sebenico in July 1841.

Finally, we found that the Herbarium Horti Botanici Pisani (PI) holds a number of Meneghini specimens. In a folder labelled "742. 4. Euhymenia dichotoma Kg." is an envelope and three sheets numbered "11". The envelope contains ten specimens of $A$. vidovichii, three of them on numbered sheets $(224,778$, 783). Two of the three sheets (upper and lower left) each have a fragment of the specimen drawn in the abovementioned plate (Fig. 7). Consequently, we designate as type material of Chondrus? vidovichii

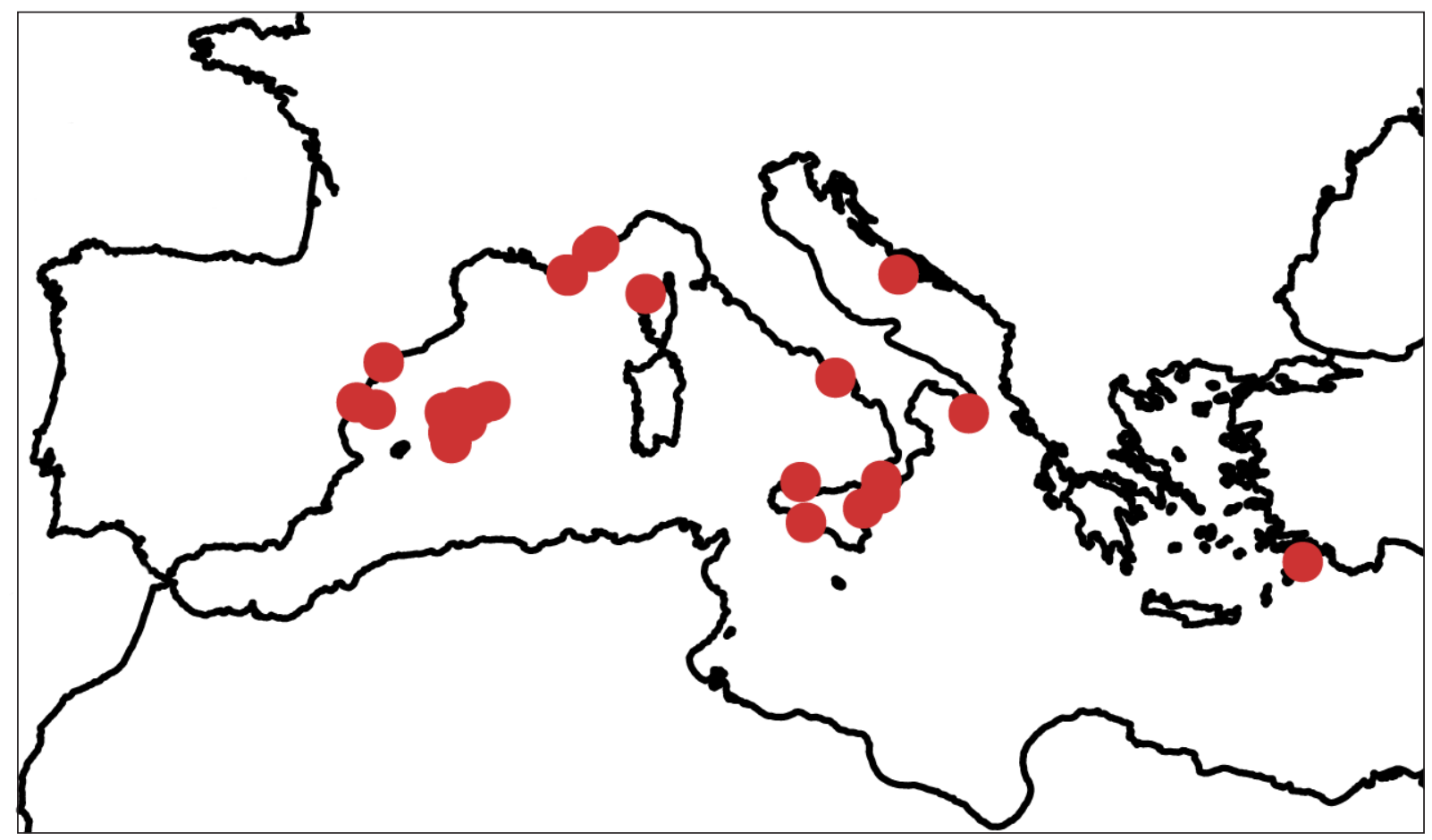

Fig. 4. Recorded sites of Acrodiscus vidovichii (Menegh.) Zanardini along the shores of the Mediterranean Sea. 


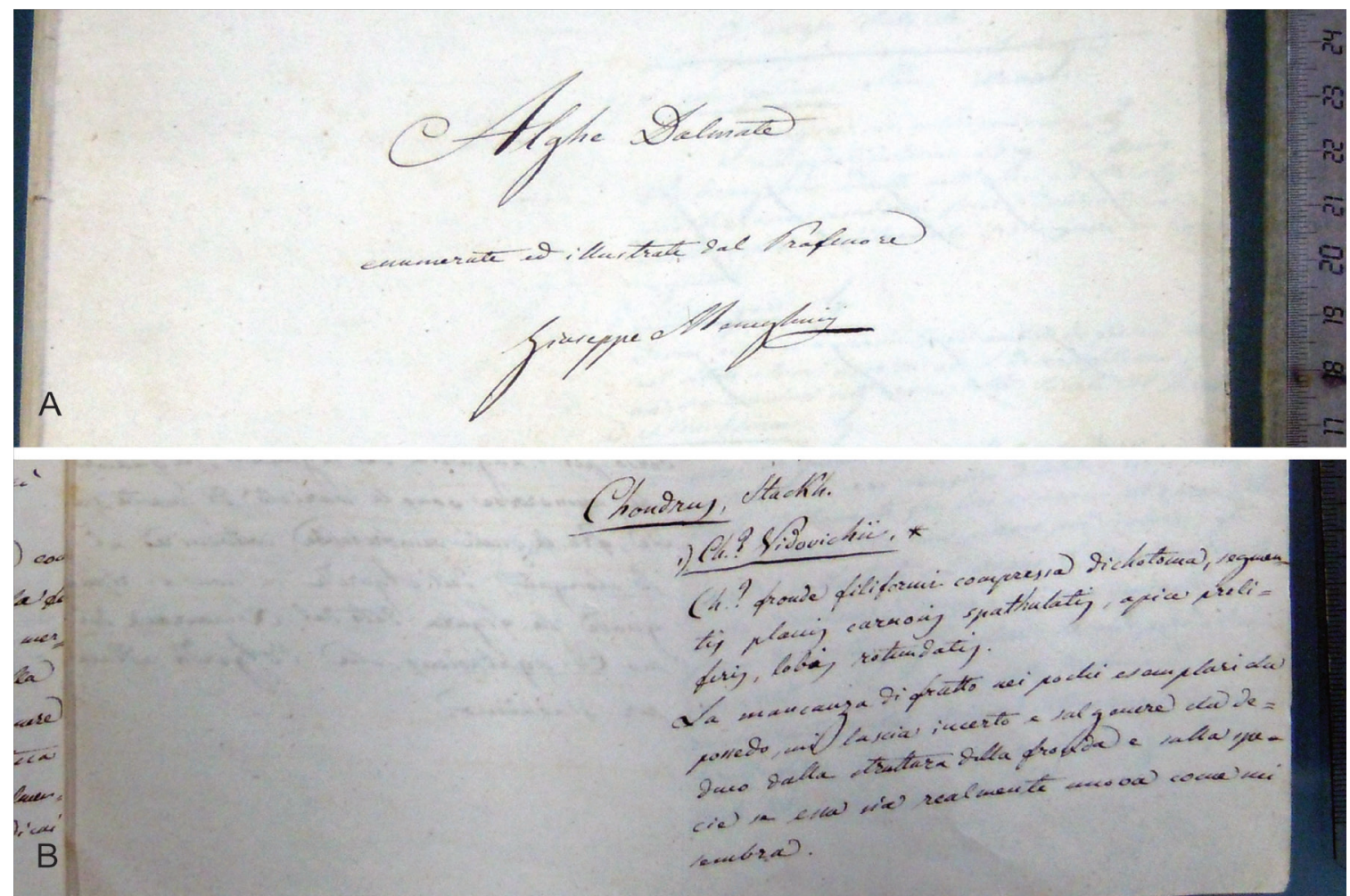

Fig. 5. A. Detail of front page of Meneghini's 1841 manuscript "Alghe Dalmate, Enumerate ed Illustrate dal Professor Giuseppe Meneghini". B. Detail of protologue page of Chondrus? vidovichii (Menegh.) Zanardini.

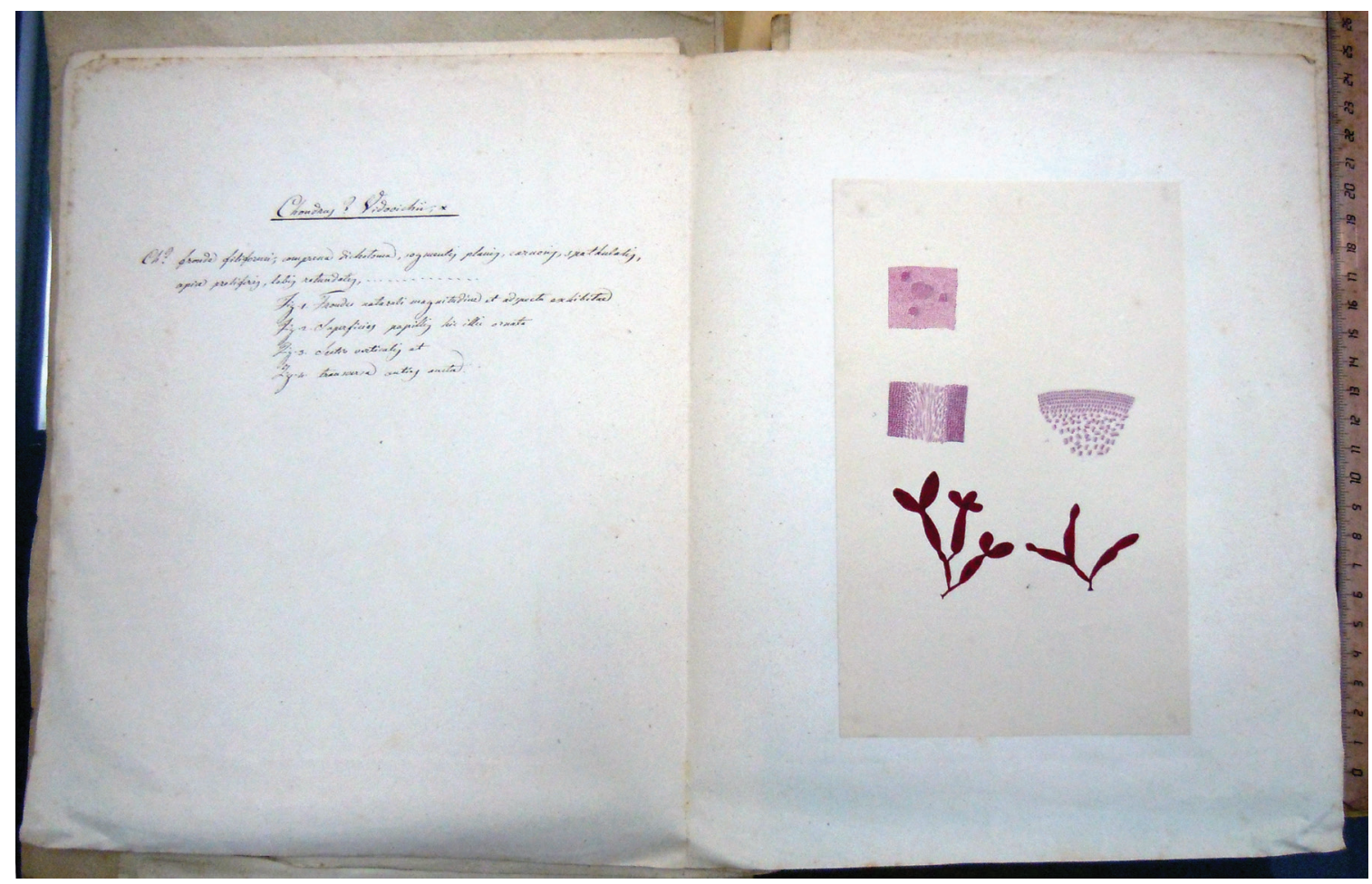

Fig. 6. Plate and caption of Chondrus? vidovichii (Menegh.) Zanardini from Meneghini's manuscript "Alghe Dalmate, Enumerate ed Illustrate dal Professor Giuseppe Meneghini". 


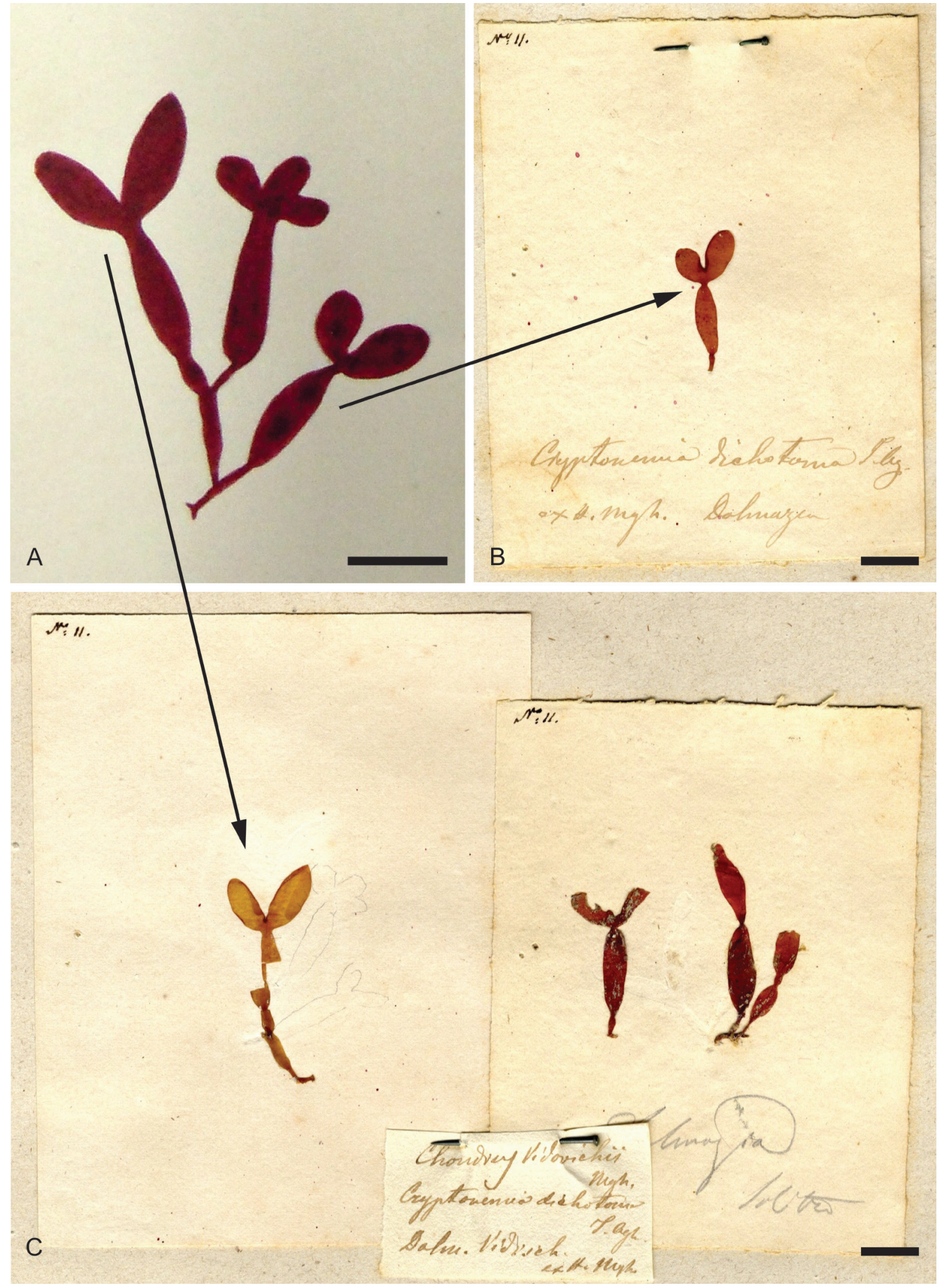

Fig. 7. Two fragments (B-C, arrows) of the specimen (A) of Chondrus? vidovichii (Menegh.) Zanardini illustrated in Meneghini's protologue manuscript. The sheets are currently filed in folder 742.4, labelled "Euhymenia dichotoma Kg." at the Herbarium Orti Botanici Pisani (PI). Scale bars $=1 \mathrm{~cm}$. 
Meneghini the two fragments on two of the "11" sheets that were portions of the single specimen he illustrated in the unpublished figure accompanying his manuscript.

\section{Phylogenetic analyses}

The DNA barcode region was generated for 15 samples from different Mediterranean localities, including the type area; the sequences are now lodged in BOLD and Genbank (Table 1). Divergence among generated sequences ranged from $0-3$ bp $(0-0.53 \%)$, which is a typical level of within-species variation.

Phylogenetic analyses inferred from both $r b c \mathrm{~L}$ and LSU markers (Fig. 8 and trees not shown) resolved three strongly supported supergeneric lineages within the Halymeniales: a) one of A. nitidissima J.Agardh and species of Pachymenia J.Agardh; b) a second comprised of Polyopes J.Agardh and Glaphyrosiphon intestinalis (Harv.) Leister \& W.A.Nelson; and c) a third consisting of Grateloupia C.Agardh, Yonagunia Kawag. \& Masuda, Pachymeniopsis Yamada ex Kawab., Prionitis J.Agardh, Phyllymenia J.Agardh, Mariaramirezia M.S.Calderon, G.H.Boo, A.Mansilla \& S.M.Boo, Kintokiocolax Tak.Tanaka \& Nozawa and Dermocorynus P.Crouan \& H.Crouan. The relationships among the remaining halymeniacean genera included in our analyses were poorly or not resolved. Cryptonemia J.Agardh was polyphyletic and Thamnoclonium Kützing was paraphyletic in $r b c \mathrm{~L}$ analyses, and the genus Halymenia C.Agardh was polyphyletic in both $r b c \mathrm{~L}$ and LSU trees.

The exact alliance of Acrodiscus was uncertain, as it varied depending on the phylogenetic reconstruction methods and the marker. In $r b c \mathrm{~L}$ analyses, A. vidovichii was included in an unsupported lineage encompassing Felicinia marginata (Roussel) Manghisi, L.Le Gall, Ribera, Gargiulo \& Morabito and Corynomorpha prismatica (J.Agardh) J.Agardh. This assemblage in turn grouped with particular, especially type, species of Halymenia, Cryptonemia, Carpopeltis F.Schmitz, Codiophyllum J.E.Gray, Spongophloea Huisman, De Clerck, Prud'homme \& Borow., Thamnoclonium Kütz., Epiphloea J.Agardh and Gelinaria Sond. In LSU trees, Acrodiscus grouped with Corynomorpha and species of Pachymeniopsis, Dermocorynus, Grateloupia and Prionitis. In concatenate LSU-rbcL analyses (Fig. 8), it was sister to Corynomorpha with variable degrees of support, both genera being included in a deeper lineage encompassing Felicinia Manghisi, L.Le Gall, Ribera, Gargiulo \& Morabito, Halymenia, Cryptonemia, Gelinaria, Epiphloea and Isabbottia M.S.Balakr.

\section{Discussion}

Our molecular analyses have highlighted the well-known fact that some genera within the Halymeniaceae are not monophyletic assemblages, with various tree topologies for the family as a whole depending both on taxon sampling and phylogenetic signals of the markers (Fig 8). None of our analyses conclusively resolved the family position of Acrodiscus Zanardini, as its alliances changed depending on the reconstruction method.

The three supergeneric lineages within the Halymeniaceae emerging from our phylogenies have already been found in previous works (Manghisi et al. 2014; Mineur et al. 2010; Nelson et al. 2014), but morphological/anatomical characteristics unifying the members of the three lineages can still not be precisely specified. The relationships among the several remaining genera represented in our analyses were poorly or not at all resolved, the polyphyly of some of them, such as Halymenia, Thamnoclonium and Cryptonemia, being clearly indicated. Studies such as those recently initiated for the complex that includes Grateloupia, Pachymeniopsis, Yonagunia and related genera (Calderon et al. 2014; Gargiulo et al. 2013) are needed before the generic relationships for the whole of the family Halymeniaceae can be satisfactorily resolved.

The anatomy of Acrodiscus is typically halymeniaceous, although in the absence of molecular data this evidence would not be definitive for family placement. Gametangial and gonimoblast structures 


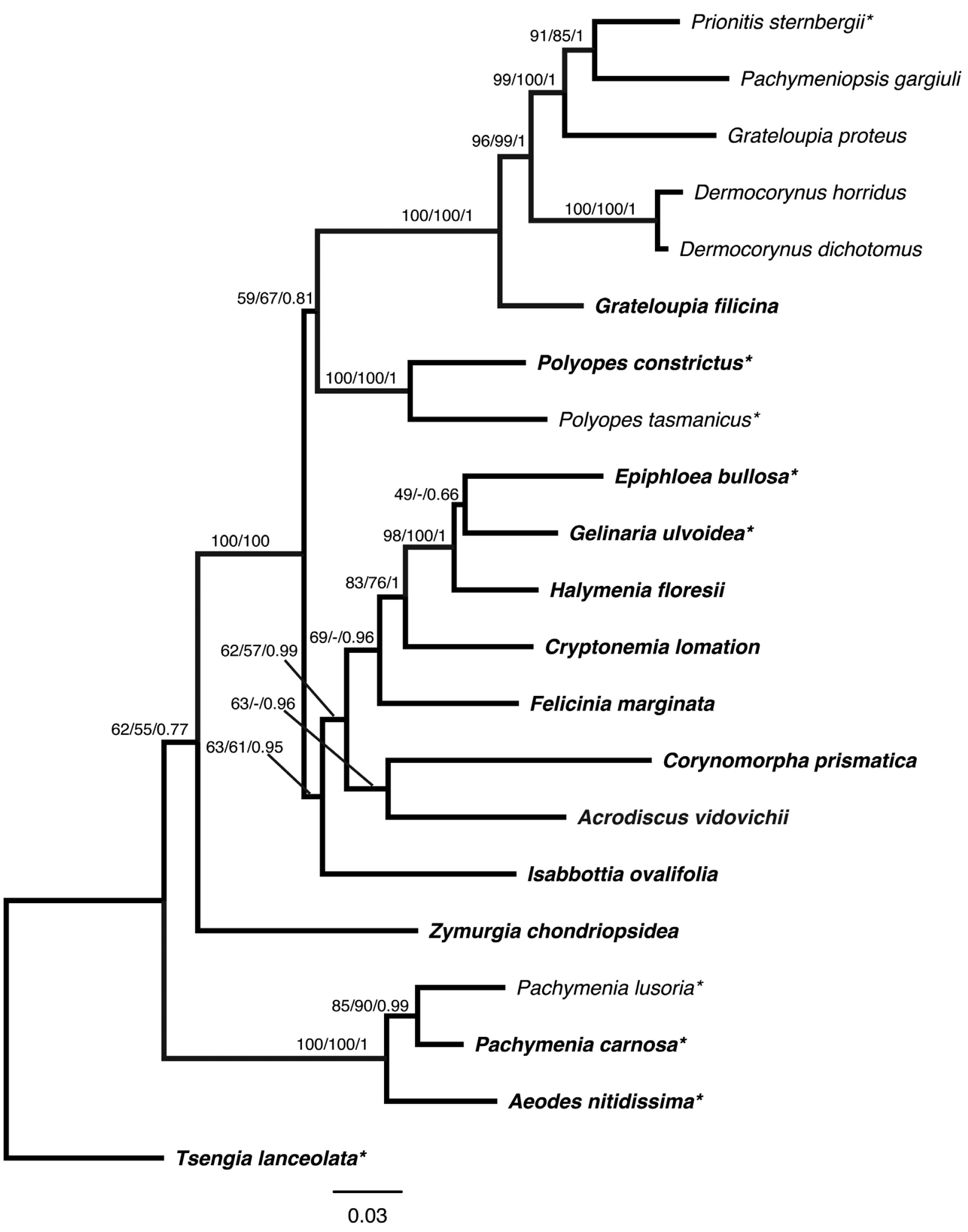

Fig. 8. ML phylogram inferred from the combined LSU-rbcL data by PhyML. Supports at nodes indicate bootstrap values (from PhyML and RaxML) and posterior probabilities inferred from Bayesian analysis. Generitype species are indicated in bold; concatenate sequences obtained from different samples for LSU and $r b c$ L are indicated by “*”. 
remain unknown despite extensive herbarium collections and our examination of some 44 specimens, although the discovery of nemathecial tetrasporangia is a strong indication that gametophytes exist in some form yet to be discovered. Should they prove to be heteromorphic or cryptic stages, this would be a first for a large family in which the members otherwise uniform in displaying isomorphic alternations of generations.

Although Schmitz (1889) provisionally included Acrodiscus in the genus Polyopes, the molecular data show that the two genera are not closely related. The grouping of Acrodiscus with the tropical genus Corynomorpha is not robust in our phylogenies, nor do habit and morphologies suggest a natural alliance. Nevertheless, this unlikely relationship should be further tested, as should a possible association with Felicinia and sistership with the Cryptonemia/Halymenia clade. For the moment we conclude on morphological and anatomical, as well and particularly on molecular, grounds that Acrodiscus is unquestionably an independent genus of the Halymeniaceae. The two poorly known species Cryptonemia crenulata and $C$. denticulata, both described by J. Agardh (1851) as having subapical sori of tetrasporangia similar to those of Acrodiscus, should be investigated as possible additional members of this presently monotypic genus.

\section{Acknowledgements}

Acquisition of molecular data was carried out at the CNRS-UMS 2700 in Service de Systématique Moléculaire, MNHN, Paris. This project was supported by the network 'Speed ID' and 'Bibliothèque du Vivant' funded by CNRS, Muséum national d'Histoire naturelle, INRA and CEA (Centre National de Séquençage) with funds provided by the ATM 'Taxonomie moléculaire: DNA Barcode et gestion durable des collections'. A.M. was the recipient of a postdoctoral grant by the Research in Paris 2010 program from the city of Paris. The authors want to thank José M. Utge, Luca Lavelli, Jordi Rull and Noemi Salvador for their help in collecting the samples. We acknowledge the following curators of herbaria for their assistance: Jenny Bryant (retired, Natural History Museum, London, UK), Florence Rousseau and Bruno de Reviers (Muséum national d'Histoire naturelle, Paris, France), Nicolien Sol and Herre Stegenga (Nationaal Herbarium Nederland, Leiden University, Leiden, the Netherlands), Chiara Nepi (Herbarium Universitatis Florentinae, Natural History Museum, Florence, Italy), Raffaella Trabucco (Natural History Museum, Venice, Italy), Rossella Marcucci (Herbarium Patavinum, Padua, Italy), Lucia Amadei and Simonetta Maccioni (Herbarium Horti Pisani, University of Pisa, Italy), as well as the librarians Giovanna Ciulli and Barbara Lapucci (Library of Natural and Enviromental Sciences, University of Pisa, Italy). A special thank goes to Paolo and Fabio Rindi for their magnificent hospitality in Pisa. The authors would also like to thank Gerry Kraft and an anonymous reviewer for their comments that greatly improved the manuscript.

\section{References}

Agardh J.G. 1842. Algae maris Mediterranei et Adriatici, observationes in diagnosin specierum et dispositionem generum Apud Fortin, Masson et $\mathrm{C}^{\mathrm{ie}}$., Parisiis [Paris].

Agardh J.G. 1851. Species genera et ordines algarum, seu descriptiones succinctae specierum, generum et ordinum, quibus algarum regnum constituitur. Volumen secundum: algas florideas complectens. Pars Prior. C.W.K. Gleerup, Lundae [Lund].

Aleem A.A. 1993. The marine algae of Alexandria, Egypt. Alexandria.

Altekar G., Dwarkadas S., Huelsenbeck J.P. \& Ronquist F. 2004. Parallel Metropolis coupled Markov chain Monte Carlo for Bayesian phylogenetic inference. Bioinformatics 20: 407-15. http://dx.doi. org/10.1093/bioinformatics/btg 427 
Ardissone F. 1883. Phycologia Mediterranea I. Floridee. Memorie della Società Crittogamologica Italiana 1: $\mathrm{i}-\mathrm{x}, 1-516$.

Athanasiadis A. 1987. A Survey of the Seaweeds of the Aegean Sea with Taxonomic Studies on Species of the Tribe Antithamnieae (Rhodophyta). XXX Thesis. University of Gothenburg. Department of Marine Botany, Gothenburg.

Bory de Saint-Vincent J.B.G.M. 1828. Famille des Halyméniées. In: Duperrey L.-I. (ed.) Voyage autour du Monde, éxécuté par Ordre du Roi, sur la Corvette de Sa Majesté, La Coquille, pendant les années 1822, 1823, 1824 et 1825. Tome 1 Botanique: 158-181. Arthus Bertrand, Paris.

Calderon M.S., Boo G.H. \& Boo S.M. 2014. Morphology and phylogeny of Ramirezia osornoensis gen. \& sp. nov. and Phyllymenia acletoi sp. nov. (Halymeniales, Rhodophyta) from South America. Phycologia 53: 23-36. http://dx.doi.org/10.2216/13-158.1

Chiang Y.M. 1970. Morphological studies of red algae of the family Cryptonemiaceae. University of California Publications in Botany 58: 1-95.

Clark K., Karsch-Mizrachi I., Lipman D.J., Ostell J. \& Sayers E.W. 2016. GenBank. Nucleic Acids Research 44: D67-D72. https://doi.org/10.1093/nar/gkv1276

Cronquist A. 1960. The divisions and classes of plants. The Botanical Review 26: 425-482. http://dx.doi. org/10.1007/BF02940572

De Toni G.B. 1905. Sylloge Algarum Omnium hucusque Cognitarum. Vol. IV. Florideae. Sectio IV. Patavii [Padova].

Ercegović A. 1949. Sur quelques algues rouges, rares ou nouvelles, de l'Adriatique. Acta Adriatica 4: $1-81$.

Feldmann J. 1939. Les algues marines de la côte des Albères. IV. - Rhodophycées. Revue Algologique 11: $247-330$.

Felsenstein J. 1985. Confidence limits on phylogenies with a molecular clock. Systematic Zoology 34: 152-61. http://dx.doi.org/10.2307/2413323

Freshwater D.W. \& Rueness J. 1994. Phylogenetic relationships of some European Gelidium (Gelidiales, Rhodophyta) species based on $r b c$ L nucleotide sequence analysis. Phycologia 33: 187-94. http://dx.doi. org/10.2216/i0031-8884-33-3-187.1

Gargiulo G.M., Morabito M. \& Manghisi A. 2013. A re-assessment of reproductive anatomy and postfertilization development in the systematics of Grateloupia (Halymeniales, Rhodophyta). Cryptogamie: Algologie 34: 3-35. http://dx.doi.org/10.7872/crya.v34.iss1.2013.3

Gascuel O. 1997. BIONJ: An improved version of the NJ algorithm based on a simple model of sequence data. Molecular Biology and Evolution 14: 685-95. http://dx.doi.org/10.1093/oxfordjournals.molbev. $\underline{\mathrm{a} 025808}$

Gouy M., Guindon S. \& Gascuel O. 2010. SeaView version 4: a multiplatform graphical user interface for sequence alignment and phylogenetic tree building. Molecular Biology and Evolution 27: 221-24. http://dx.doi.org/10.1093/molbev/msp259

Guindon S. \& Gascuel O. 2003. A simple, fast, and accurate algorithm to estimate large phylogenies by Maximum Likelihood. Systematic Biology 52: 696-704. http://dx.doi.org/10.1080/10635150390235520

Guiry M.D. \& Guiry G.M. 2016. AlgaeBase [online]. Available from http://www.algaebase.org [accessed 27 Jan. 2016]. 
Harper J.T. \& Saunders G.W. 2001. Molecular systematics of the Florideophyceae (Rhodophyta) using nuclear large and small subunit rDNA sequence data. Journal of Phycology 37: 1073-82. http://dx.doi. org/10.1046/j.1529-8817.2001.00160.x

Hauck F. 1885. Die Meeresalgen Deutschlands und Österreichs. Eduard Kummer, Leipzig.

Huelsenbeck J.P. 2002. Testing a covariotide model of DNA substitution. Molecular Biology and Evolution 19: 698-707. http://dx.doi.org/10.1093/oxfordjournals.molbev.a004128

Kraft G.T. \& Saunders G.W. 2014. Crebradomus and Dissimularia, new genera in the family Chondrymeniaceae (Gigartinales, Rhodophyta) from the central, southern and western Pacific Ocean. Phycologia 53: 146-166. http://dx.doi.org/10.2216/13-213.1

Kützing F.T. 1849. Species Algarum. F.A. Brockhaus, Lipsiae [Leipzig].

Kützing F.T. 1867. Tabulae Phycologicae; oder, Abbildungen der Tange. Vol. 17. W. Köhne, Nordhausen.

Kylin H. 1956. Die Gattungen der Rhodophyceen. Gleerups, Lund.

Manghisi A., Gómez Garreta A. \& Ribera M.A. 2010. Mapas de distribución de algas marinas de la península Ibérica y las islas Baleares. XXV. Acrodiscus vidovichii (Meneghini) Zanardini and Aeodes marginata (Roussel) F. Schmitz (Halymeniales, Rhodophyta). Botanica Complutensis 34: 95-98.

Manghisi A., Morabito M., Bertuccio C., Le Gall L., Couloux A., Cruaud C. \& Genovese G. 2010. Is routine DNA barcoding an efficient tool to reveal introductions of alien macroalgae? A case study of Agardhiella subulata (Solieriaceae, Rhodophyta) in Cape Peloro lagoon (Sicily, Italy). Cryptogamie: Algologie 31: 423-433.

Manghisi A., Le Gall L., Ribera M.A., Bonillo C., Gargiulo G.M. \& Morabito M. 2014. The Mediterranean endemic new genus Felicinia (Halymeniales, Rhodophyta) recognized by a morphological and phylogenetic integrative approach. Cryptogamie, Algologie 35: 221-43. http://dx.doi.org/10.7872/crya. v35.iss 3.2014.221

Mineur F., De Clerck O., Le Roux A., Maggs C.A. \& Verlaque M. 2010. Polyopes lancifolius (Halymeniales, Rhodophyta), a new component of the Japanese marine flora introduced to Europe. Phycologia 49: 86-96. http://dx.doi.org/10.2216/09-45.1

Nelson W.A., Kim S.Y. \& Boo S.M. 2014. Transfer of the subantarctic red alga Grateloupia aucklandica to the genus Glaphyrosiphon (Halymeniales, Rhodophyta). Phycologia 53: 457-462. http://dx.doi. org/10.2216/14-017.1

Preda A. 1908. Flora Italica Cryptogama Pars II: Algae - Vol. 1 Fasc. 2. L. Cappelli, Rocca San Casciano.

Ronquist F. \& Huelsenbeck J.P. 2003. MrBayes 3: Bayesian phylogenetic inference under mixed models. Bioinformatics 19: 1572-1574. http://dx.doi.org/10.1093/bioinformatics/btg180

Saunders G.W. \& Kraft G.T. 1996. Small-subunit rRNA gene sequences from representatives of selected families of the Gigartinales and Rhodymeniales (Rhodophyta). 2. Recognition of the Halymeniales ord. nov. Canadian Journal of Botany 74: 694-707. http://dx.doi.org/10.1139/b96-088

Saunders G.W. \& Hommersand M.H. 2004. Assessing red algal supraordinal diversity and taxonomy in the context of contemporary systematic data. American Journal of Botany 91: 1494-1507. http://dx.doi. org/10.3732/ajb.91.10.1494

Saunders G.W. \& McDevit D.C. 2012. Chapter 10. Methods for DNA barcoding photosynthetic protists emphasizing the macroalgae and diatoms. In: Kress W.J. \& Erickson D.L. (eds) DNA Barcodes: Methods and Protocols: 207-22. Humana Press, New York. 
Savi P. 1841. Sezione di botanica, e fisiologia vegetabile. Adunanza del dì 16 Settembre 1841. In: Atti della Terza Riunione degli Scienziati Italiani, tenuta in Firenze nel Settembre del 1841: 424-31. Galileiana, Firenze.

Schmitz F. 1889. Systematische Übersicht der bisher bekannten Gattungen der Florideen. Flora 72: 435-456.

Swofford D.L. 2002. PAUP*. Phylogenetic Analysis Using Parsimony (*and Other Methods), v. 4.0b10. Sinauer Associates, Sunderland, Massachusetts.

Thiers B.M. Continously updated. Index Herbariorum: A Global Directory of Public Herbaria and Associated Staff [online]. Available from http://sweetgum.nybg.org/ih/ [accessed 27 Jan. 2016].

Wang H.W., Kawaguchi S., Horiguchi T. \& Masuda M. 2000. Reinstatement of Grateloupia catenata (Rhodophyta, Halymeniaceae) on the basis of morphology and $r b c \mathrm{~L}$ sequences. Phycologia 39: 228237. http://dx.doi.org/10.2216/i0031-8884-39-3-228.1

Wettstein R.V. 1901. Handbuch der systematischen Botanik. Vol. 1. Franz Deuticke, Leipzig and Vienna.

Withall R. \& Saunders G.W. 2006. Combining small and large subunit ribosomal DNA genes to resolve relationships among orders of the Rhodymeniophycidae (Rhodophyta): recognition of the Acrosymphytales ord. nov. and Sebdeniales ord. nov. European Journal of Phycology 41: 379-394. http://dx.doi.org/10.1080/09670260600914097

Womersley H.B.S. \& Lewis J.A. 1994. Family Halymeniaceae Bory 1828: 158. In: Womersley H.B.S. (ed.) The Marine Benthic Flora of Southern Australia. Part IIIA. Bangiophyceae and Florideophyceae (Acrochaetiales, Nemaniales, Gelidiales, Hildebrandiales and Gigartinales sensu lato): 167-218. Australian Biological Resources Study, Canberra.

Zanardini G. 1843. Saggio di Classificazione Naturale delle Ficee, del Dottor Giuseppe Zanardini aggiunti Nuovi Studii sopra l'Androsace degli Antichi con Tavola Miniata ed Enumerazione di tutte le Specie Scoperte e Raccolte dall'Autore in Dalmazia. Girolamo Tasso, Venice.

Zanardini G. 1868. Scelta di ficee nuove o più rare dei mari Mediterraneo ed Adriatico. Figurate, descritte ed illustrade dal M.E. Dott. G. Zanardini. Memorie del Reale Istituto Veneto di Scienze, Lettere ed Arti 14: 179-216.

Manuscript received: 11 February 2016

Manuscript accepted: 28 April 2016

Published on: 31 January 2017

Guest editors: Line Le Gall, Frédéric Delsuc, Stéphane Hourdez, Guillaume Lecointre

and Jean-Yves Rasplus

Handling editor: Koen Martens

Desk editor: Danny Eibye-Jacobsen

Printed versions of all papers are also deposited in the libraries of the institutes that are members of the EJT consortium: Muséum national d'Histoire naturelle, Paris, France; Botanic Garden Meise, Belgium; Royal Museum for Central Africa, Tervuren, Belgium; Natural History Museum, London, United Kingdom; Royal Belgian Institute of Natural Sciences, Brussels, Belgium; Natural History Museum of Denmark, Copenhagen, Denmark; Naturalis Biodiversity Center, Leiden, the Netherlands. 


\section{Appendix}

\section{Description of the historical herbarium material studied for the lectotypification of Chrondrus ? vidovichii Menegh.}

Koster (1969) suggested that the Meneghini collection might be in Florence (FI) or in Kützing's collections, which are in Leiden (L) or London (BM). Therefore, the Herbarium Universitatis Florentinae was searched for the type of Meneghini, and we found that sheet FI 4796-1 holds five sub-sheets, each with a specimens of Acrodiscus vidovichii, without locality, date or collector. Four of them are from Herbarium Meneghini; the fifth one is mounted on a slide and accompanied by a manuscript annotation "Chondrus vidovichii col frutto, un pezzo del quale si staccò dalla cima e lo comprendo. - Sentirò con piacere che a quest'alga ha levato per sempre il punto interrogativo". ["Chondrus vidovichii with fruit, a fragment of which detached from the tip and I include it. - I will hear with pleasure that you have removed the question mark from this alga for ever".]

The manuscript annotation has been compared to Meneghini manuscript documents, and the writing is different. The annotation is from someone sending a fertile specimen to Meneghini and hoping he will eliminate the question mark from Chondrus? vidovichii. The fact that the specimen is fertile is actually an argument to posit that it cannot belong to Meneghini's original material at the time he described the species. For the remaining specimens there is no clear evidence of their being paratypes.

From the Nationaal Herbarium Nederland (L) we received on loan three herbarium sheets of A. vidovichii. L 0833934 belonged to Herbarium Suringar and has a single specimen with the manuscript label “Cryptopleura vidovichii Dalmazia!", but without mention of either a date or a collector. L 0833935 belonged to Herbarium Kützing and has two specimens, with the manuscript label "Cryptonemia vidovichii, * Chondrus vidovichii, Menegh. 1841 Cryptonemia dichotoma, J. Ag. 1842", the collector/ sender is Meneghini and the locality is Dalmatia; nevertheless, there is no mention of a date. The two specimens were drawn by Kützing in his Tabulae Phycologicae vol. 17 (Kützing 1867: tav. 72, fig. d-e). Kützing in his Species Algarum (1849: 742) wrote "specim. dedit amic. Menghini", maybe in reference to these specimens. L 0833936 consists of two sheets. The first one holds a specimen and fragment in a small envelope, with the manuscript label "Acrodiscus vidovichii Dalmazia lg. Vidovich", but without a date. The second sheet holds a single specimen, with the manuscript label "Acrodiscus vidovichii lg. Vidovich, com. Zanardini Dalmazien", and without date, but has another annotation in the upper part referring to Zanardini's Iconographia Phycologica Adriatica tv. LXIX, fig. 3. In fact, the specimen corresponds to the one drawn in that figure.

In the Herbarium of the Natural History Museum of London (BM) we found the herbarium sheet BM000619430, with the manuscript label "Cryptonemia dichotoma J. Agardh, 1841 Nizza J. Agardh" (ex Herbarium Griffiths), which is original material of Cryptonemia dichotoma J. Agardh 1842. Also BM000563717 and BM000563718 are both from Nizza and ex Herbarium J.G. Agardh, but without a date. Another interesting sheet is BM000569934, with the manuscript label "Acrodiscus vidovichii, Dalmazien, lg. Vidovich" (ex Herb. Weber van Bosse), because the specimen was collected at the type locality (topotype) by Vidovich, the same collector that sent material to Meneghini.

Unable to find suitable material for the lectotypification in the herbaria suggested by Koster (1969), we extended our search to other herbaria. In the Muséum national d'Histoire naturelle de Paris (PC) there are three interesting specimens/sheets. The first one, PC0047928 (MA2052), is labelled "Cryptonemia vidovichii Zan. (Chondrus? vidovichii Menegh., Cryptonemia dichotoma J. Ag.) Meneghini-Dalmazia"; thus, it belonged to Meneghini and was collected in Dalmatia, but there is no reference to the date of collection. The second one, PC0523534 (AR24258), is labelled "Cryptonemia dichotoma J Ag. , Nizza - 
J. Agardh 1840"; it is original material of Cryptonemia dichotoma J.Agardh. The third one, PC0474569, is labelled Acrodiscus vidovichii, Zanard. and belonged to Herbarium Zanardini.

We also searched in the Natural History Museum of Venice (MCVE), in the Herbarium Zanardini, where we found two sheets, four envelopes and two hand-drawn tables. The first sheet has two specimens of A. vidovichii from the Gulf of Naples, collected by Pedicino, while the second sheet has a specimen in two pieces/fragments from Dalmatia, with no collector cited. The first envelope on the left holds various small specimens. The second envelope, above in the middle, has a hand-written notation (con fruttificazione) and an unclear name, maybe the collector. It holds three small fertile specimens. The third envelope, below in the middle, is marked "Chondrus vidovichii Menegh." and holds a single specimen. The fourth envelope, on the right, is marked "Chryptonemia vidovichii, Z." and holds four small specimens. The two hand-drawn tables correspond to table VIII published in Zanardini (Zanardini 1868) or LXIX in (Zanardini 1871). Note that the drawn specimen n. 4 corresponds to the one in two fragments from Dalmatia.

Subsequently, following Meneghini's biography we also searched in Padua, where he taught until 1848, and then in Pisa, where he resided and taught after 1849.

The Herbarium Patavinum (PAD) of Padua, Italy, holds a small specimen of $A$. vidovichii in an envelope (PAD A00389). The envelope recites "Chondrus vidovichii Mgh! Dalmatia leg. Vidovich ex Herb Mgh! Beccari". However, lacking a date, it is not a good candidate for type material.

All the above-mentioned herbarium material is listed in Table 2.

\section{References}

Koster J.T. 1969. Type collections of algae. Taxon 18: 545-59. http://dx.doi.org/10.2307/1218384

Kützing F.T. 1849. Species Algarum. F.A. Brockhaus, Lipsiae [Leipzig].

Zanardini G. 1868. Scelta di ficee nuove o più rare dei mari Mediterraneo ed Adriatico. Figurate, descritte ed illustrate dal M.E. Dott. G. Zanardini. Memorie del Reale Istituto Veneto di Scienze, Lettere ed Arti 14: 179-216, pls IV (LXV) - XIV (LXXII).

Zanardini G. 1871. Iconographia Phycologica Adriatica ossia scelta di Ficee nuove o più rare del Mare Adriatico figurate, descritte ed illustrate da G. Zanardini. Vol. III. G. Antonelli, Venice. 